\title{
Laonikos a magyar nép nevéről ${ }^{*}$
}

\section{Dis manibus J. Vekerdi}

1. Laonikos és történeti müve. A bizánci történetírás utolsó nagy korszakát képviselő kvartett Sphrantzés, Dukas és Kritobulos mellett negyedik, meghatározó alakja az athéni Laonikos Chalkokondylés. A török birodalom felemelkedéséról szóló müvének irodalomtörténeti jelentősége csak részben áll egyedi témaválasztásában, bár a rohamosan terjedő ,,új hit”, az iszlám bemutatása már önmagában is különlegesnek számít a 15. századi „nyugati” irodalomban. Laonikos igazi erénye mégis inkább a legnagyobb klasszikus auctorokat idéző, mindenféle részrehajlástól mentes ábrázolásmód, mely a hitéleti kérdésekben általában szélsőségesen nyilatkozó, többnyire erôsen elfogult szerzők stílusához képest üdítő kivételt jelent. Laonikost ráadásul Fortuna is kegyeibe fogadta, amennyiben befejezetlenségében is meglehetösen

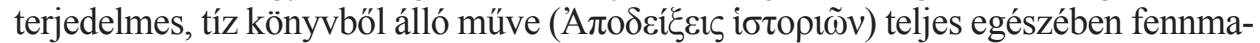
radt. Bár a jelen tanulmányban vizsgált kérdés szempontjából közel sem mellékes, a mü keletkezési idejét csak találgatni tudjuk. A korábbi tudományos konszenzus az 1480-as évekre datálta Laonikos munkáját (MisKOLCZI 1913; vö. TALBOT 1991), mások 1470 körülre (WURM-GAMILLSCHEG 1992), újabban pedig akad, aki még korábbra, 1464 és 1468 közé helyezi a mü megszületésének időpontját (KALDELLIS 2012). A bizonytalanságot csak fokozza, hogy a szerző életéről szintén nagyon kevés adattal rendelkezünk, pályája az 1450-es évek után szinte teljesen ismeretlen.

Amint az közismert, a mủ cselekményének fó szálát Laonikos előszeretettel színezi néprajzi-földrajzi kitérőkkel. A mü terjedelmének csaknem harmada etnográfiai exkurzus: az olvasó találkozhat szlávokkal, germánokkal, franciákkal és britekkel, de bepillanthat a mongolok, indek, egyiptomiak, vagy éppen az itáliai városállamok némelyikének (Velence, Genova, Firenze) történetébe is. A magyarokat az „új Hérodotos” - ahogy újabban megjelent monográfiájában ANTHONY KALDELLIS nevezi Laonikost (KALDELLIS 2014b) - elöször a II. könyvben, a Luxemburgi Zsigmond vezette, hamvába holt keresztes hadjárat (1396) kapcsán említi részletesebben, de később is többször belesző a történetbe a magyar nép történelmével kapcsolatos eseményeket, adatokat. Jelen alkalommal az első hosszabb szöveghely egyik problematikus részletével kívánunk foglalkozni.

2. A magyar népnév Laonikosnál. Miután Laonikos röviden ismertette Magyarország (nála: Пaıovía) földrajzi elhelyezkedését, bemutatta a kormányzati rendszert (a királyok idegen uralkodóházakból származnak, ismerik a kormányzói tisztséget), majd a kitérőkben szokásos föbb szempontok szerint futólag említést tett a nép néhány jellemző tulajdonságáról (vallás, életmód, szokások), áttér a magyarok eredetének, nyelvének kérdésére is. A szóban forgó fejezet (II, 17) bennünket most közelebbről érdeklő részlete KAPITÁNFFY ISTVÁN fordításában a kö-

\footnotetext{
*A tanulmány az OTKA K 116371 jelzetü pályázat támogatásával készült.
} 
vetkezőképp hangzik: „Nyelvük egyáltalán nem hasonlít egyetlen más nemzetéhez sem, teljesen elüt a germánokétól, boemosokétól és polanosokétól. Néhányan azt tartják, hogy hajdan geták voltak, s midőn a Haimos tövében laktak, vereséget szenvedtek a skytháktól, és arra a vidékre költöztek, ahol most is laknak. Mások szerint dákok voltak. Én magam nem tudnám így egyszerüen megmondani, milyen nép volt eredetileg; mindenesetre ők maguk is és a z itáliaiak is ezt a nevet has ználják ráj u k, s jószerével nem tudnám másképp hívni őket." ( $\varphi \omega v \tilde{n} \delta \varepsilon$

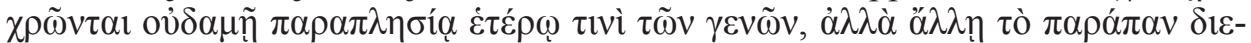

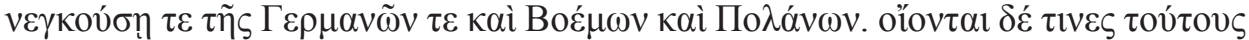

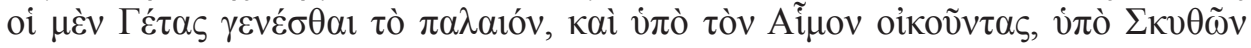

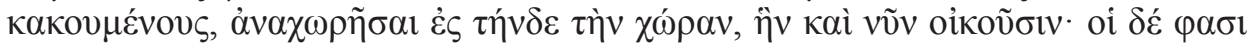

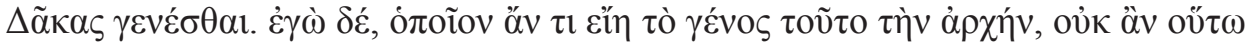

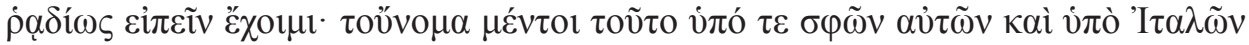

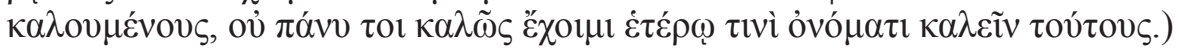

Bár a kissé elnagyolt leírás számos apróbb érdekességet tartalmaz, vizsgálódásunk ezúttal kizárólag a magyar népnévre irányul. Csakhogy a magyarok neve az idézett szemelvényből expressis verbis nem derül ki: a népnevet Laonikos névmá-

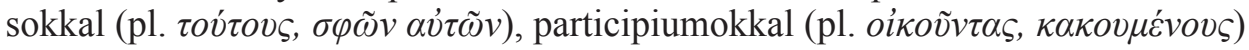
helyettesíti, a magyarokra vonatkozó állítmányok mellett pedig nem teszi ki az

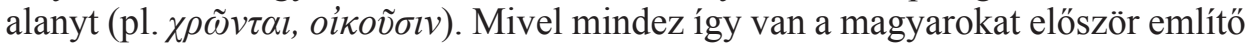
és érdemben bemutató teljes, in extenso nem idézett fejezetben is, az a különös helyzet áll elö, hogy a szerző minden lényegesnek tartott információt közöl velünk, magyarokkal kapcsolatban, csak éppen a nép nevét nem említi.

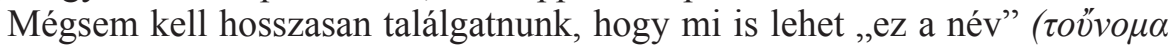

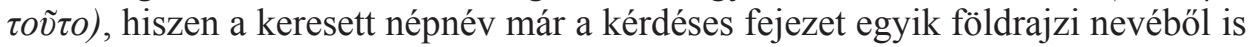
kikövetkeztethető. Ha ugyanis a Magyar Királyság neve Iaıoví $\alpha$, akkor vélhetően a magyarok neve is a $\Pi \alpha i o v \varepsilon \varsigma$ (pluralis nominativus) alakban fog szerepelni.

A teljes mü áttekintése egyértelmüen igazolja sejtésünket, annál is inkább, mert a szóválasztás kérdésében Laonikos szerencsére következetesnek bizonyul. A Magyar Királyság nála mindig П\ıovía (a teljes müben az ország neve a függő esetekkel együtt tizenegy alkalommal fordul elö), a magyarok pedig mindig egy-

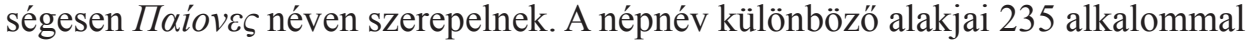
fordulnak elő a müben, de emellett találkozhatunk az ugyanebből a tőből képzett

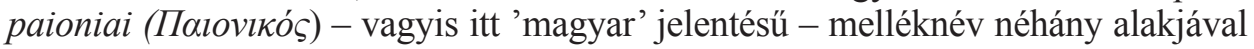
(összesen négy esetben). Meg kell jegyeznünk továbbá, hogy Laonikos Erdély megnevezésére - a szokottabb A $\rho \delta \varepsilon ́ \lambda ı o v$ alak (tizenhárom előfordulás) mellett - nyolc

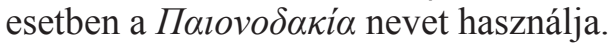

Amennyire a nemzetközi bizantinológiai szakirodalom hivatkozásaiból, illetve helyenként azok hiányából látszik, ez a névhasználat, és különösen Laonikos annak igazolásául hozzáfüzött megjegyzése további magyarázatot kíván. Hogy a Паioves-kérdésre miért nem tér ki a Laonikos müvéhez írt egyetlen - töredékes kommentár (NICOLOUDIS 1996 szó nélkül hagyja a kérdéses szöveghelyet), az csak akkor válik érthetővé, ha fellapozzuk a Chalkokondylés-kutatás elismert tekintélyének, ANTHONY KALDELLISnek idevágó sorait (ezeket saját fordításomban közlöm). KALDELLIS ugyanis határozottan zavarban van; a névhasználatot külö- 
nösnek, megmagyarázhatatlannak tartja. A mü általa készített angol fordításának a megfelelő szöveghelyhez csatolt jegyzetében a következőket írja (KALDELLIS

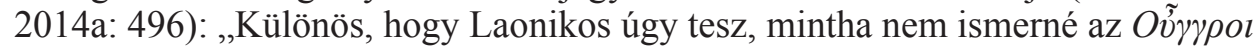
népnevet, holott ez a forma számított elterjedtnek a bizánci és nemzetközi nyelvhasználatban. Nem világos továbbá az sem, hogy milyen névre gondol, mikor azt mondja: »ez a név«. Feltehetően a Пaíoves-re, amit ő is használ, csakhogy a magyarok nem hívták így magukat.” Később pedig, a szerzőről szóló monográfiájában szinte megismétli korábbi véleményét (KALDELLIS 2014b: 64-65): „Nem

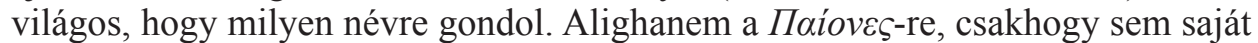
maguk, sem az itáliaiak nem ezen a néven nevezték a magyarokat. Aeneas például Commentarii címü mủvében Hungari néven említi őket. Ráadásul a bizánci

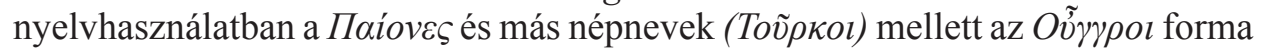
terjedt el. Feltehetően egy ellenőrzés nélkül maradt vagy homályosan fogalmazott szöveghelyröl van szó."

Ớsszegezve tehát KALDELLIS a következő kérdésekre nem talál magyarázatot: a) Laonikos miért nem a bizánci történetírók körében is ismert és elterjedt $O \tilde{v} \gamma \gamma \rho o l$ névalakot használja a magyarok megnevezésére? b) Pontosan milyen névre vonatkozik az „ezt a nevet használják” megfogalmazás? c) Hogyan kell értenünk az „ők maguk is és az itáliaiak is ezt a nevet használják" fordulatot? Végül, mivel fentiek egyikére sem tud elfogadható magyarázatot kínálni, felveti a hiba, a szövegromlás lehetőségét. Magunk nem látjuk ennyire sötéten a helyzetet, már csak azért sem, mert a második kérdés - amint ezt láttuk, s ahogy azt KALDELLIS is gyanítja - nem

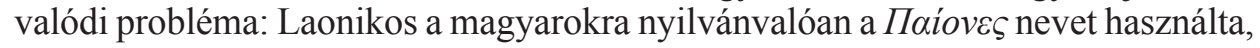
tehát az idézett helyen is arra gondolt, még ha nem is mondta ki egyértelmüen.

3. A magyar népnév a bizánci forrásokban. Kétségtelen ugyanakkor, hogy Laonikos választhatott volna más nevet is, hiszen a bizánci történeti források a magyar népnév kifejezésére számos különböző görög formát használtak. Nem véletlen, hogy ez a téma a magyar bizantinológia hőskorában különösen népszerü kutatási területnek számított: többek között DARKÓ JENŐ (1910, 1912), majd CZEBE GyUla (1925), MoRAVCSIK GyUla (1929-1930), később pedig az ő tanítványa, GYÓNI MÁTYÁs (1938) is önálló munkát szentelt a magyar nép bizánci forrásokban előforduló nevei vizsgálatának. Kutatásaik az adatolható, a görög nyelvü írásos emlékanyagban (történeti müvek, krónikák, levelek, hagiográfiai müvek, oklevelek, rendeletek és egyéb hivatalos feljegyzések) megtalálható előfordulási helyek összegyüjtésére, elemzésére és a névhasználat általános jelenségeinek magyarázatára irányultak. A vizsgált corpus felölelte a 15. században keletkezett munkákat, így Laonikos Chalkokondylés müvét is.

Tévedés lenne azt gondolnunk, hogy DARKÓnak és társainak munkáját manapság, a digitális adatbázisok korában egy gyors keresőprogrammal akár egy laikus is könnyedén elvégezhetné, hiszen nem pusztán szöveghelyek kat a lo g i zálá s á ró 1 van szó. A Паíoves név előfordulása például igen elterjedt, de a rendkívül nagy számú locusból bennünket csakis azon helyek érdekelnek, ahol a név kimondottan és kizárólag a magyarokra vonatkozik. Más szóval elkerülhetetlen a források aprólékos elemzése. 
A jeles elődök számunkra ezúttal fontos eredményei az alábbi pontokban foglalhatóak össze:

A) A bizánci források a magyarok nevére a következő, összesen tizennyolc ne-

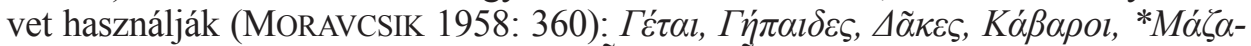

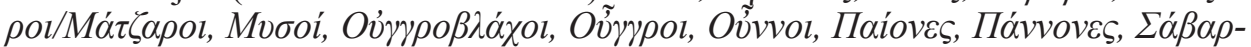

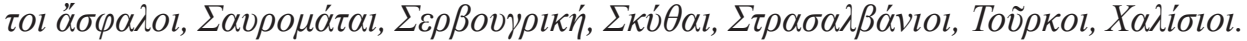

Ezeket a neveket MORAVCSIK (1929-1930) három nagyobb csoportba osztotta: a) kizárólag a magyarokra használt népnevek, b) etnikai gyűjtőfogalomként használatos nevek, valamint c) ún. a r chai záló népnevek. Utóbbi

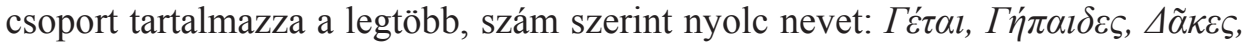

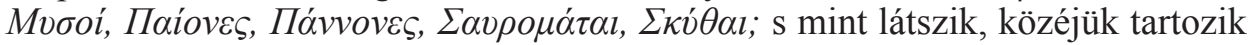
a Maíoves népnév is.

Az archaizálás a bizánci szerzőknek a klasszikus örökség fenntartására irányuló legfőbb formai eszköze. A cél a historia continua látszólagos megszakítatlanságának fenntartása: mintha az antik irodalmi hagyomány soha nem tört volna meg, mintha a bizánciak még mindig Hérodotos és Thukydidés korában élnének, mintha még mindig az ő nyelvüket beszélnék. Ennek az élőnyelvtől élesen elkülönülő purista nyelvhasználatnak szélsőséges megnyilvánulása, mikor egyegy szerző már nem éri be annyival, hogy következetesen a mintának tekintett „klasszikus” auctorokat követve, ún. atticista stílusban fogalmaz, hanem még a tulajdonnevek használatában is antik előképek felhasználására törekszik. Anna Komnéné például egyenesen elnézést kér olvasóitól, ha ókori előzmény híján olykor-olykor kénytelen bizonyos népeket vagy földrajzi helyeket a saját korában használatos névvel illetni, mivel felfogása szerint ezzel vét müve stiláris tökéletessége ellen. De ugyanez a jelenség figyelhető meg Zósimosnál, aki a hunokat a Hérodotostól kölcsönzött királyi szkíták néven emlegeti, vagy éppen Niképhoros Grégorasnál, aki pedig a tatárokat nevezi szkítáknak, és a sort még hosszan folytathatnánk (vö. MORAVCSIK 1966: 366-377).

A katalógus egyéb népneveivel ezúttal nem foglalkozunk, csak utalunk arra, hogy az egyes nevek magyarázatát illető szakirodalom meglehetősen kiterjedt (1. pl. a Kónstantinos Porphyrogennétosnál előforduló rejtélyes $\Sigma \alpha ́ \beta \alpha \rho \tau o l ~ \not ̋ \sigma \varphi \alpha-$ $\lambda o \imath$ névre vonatkozó kutatásokat, melyeket legutóbb BENKÖ LORÁND összegzett; BENKŐ 2009: 99-120). A szintén a Bíborbanszületett császár müvében talált Mó $\zeta \alpha-$ $\rho o \imath$ alakról meg kell jegyeznünk, hogy azt MORAVCSIK egyértelmủ másolási hibának tekintette, szerinte az eredeti forma $X \alpha \dot{\zeta} \zeta \alpha \rho o$ lehetett, vagyis itt nem a magyarok, hanem a kazárok nevéről van szó (MORAVCSIK 1929-1930: 247, 2. jegyzet).

B) A nyilvánvalóan különböző népek magyarokkal való téves azonosítása mögött mindig áll legalább egy $\mathrm{k}$ ö z ö s p o n t, mely kapcsolatot jelent az adott nép és magyarok között, s mint ilyen, alapot szolgáltat az azonosításra. Ahogy MORAVCSIK GYULA (1934: 245) fogalmaz: „Gyakran megfigyelhető jelenség, hogy a bizánciak a korukban feltünő népek tényleges neve mellett vagy a helyett egy másik, ókori nép nevét használják s az illető népet egy, az antikvitásból ismert néppel azonosítják. Az azonosítás rendesen a földrajzi helyzet azonosságán alapszik, de lehetnek más okai is, így például szerepet játszik az ethnográfiai sajátságok egyezése és ritkábban a nevek hasonlósága is". 
C) Az egyes népnevek megválasztásában - az elszigetelten előforduló esetektől eltekintve - időről-időre felismerhetőek bi zonyos tendenciák: a névhasználat módját alapvetően befolyásolhatta egy-egy jelentősebb szerző tekintélye, vagy éppen az adott korszak általános gyakorlata, esetleg a korban elfogadott esztétikai ízlésből fakadó elvárás.

Így például egyértelműnek tűnik, hogy a 10. században a Toṽ $\kappa$ ко forma magyarokra történő szinte kizárólagos használata VI. (Bölcs) Leó és fia, VII. Kónstantinos (Porphyrogennétos) hatásának köszönhető. Mivel ők - illetve az általuk kezdeményezett gyüjtő- és kivonatolómunka közremüködői - ezt a névalakot használták, a közvetlen környezetükhöz tartozó szerzők is kötelezőnek érezték magukra nézve, hogy a téves azonosítás ellenére ugyanezzel a formával nevezzék meg a magyarokat. Ezért szerepel a Tог̃ ко alak 'magyarok' jelentéssel a Theophanés krónikájához írott folytatásban (Theophanés Continuatus), mely szintén Kónstantinos irányítása alatt készült, és ezért vette át ezt az alakot a császár környezetében müködő Genesios, valamint Symeón Logothetés (és Pseudo-Symeón) is. Aztán feltehetően a köznyelvi használat hatására, annak eredményeként a 11. század végétől a 12. század végéig az írásos anyagban is szép lassan átbillen a mér-

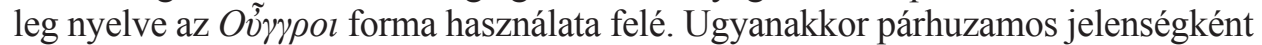
nem szünik meg az archaizáló névhasználati gyakorlat sem.

Ami a bennünket most közelebbről érdeklő Пaíoveৎ alakot illeti, ennek használatát - amennyire látszik - az archaizáló, a klasszikus szerzőket megkérdője-

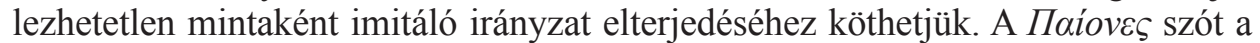
magyarokra vonatkoztatva a 11. század végétől kezdve használták, először feltehetően Nikolaos Kalliklés (Carm 2, 23), a történetírók közül pedig elsőként Ióannés Kinnamos és Nikétas Chóniatés, majd Geórgios Pachymerés, a császárként is ismert Ióannés Kantakuzénos, Laonikos Chalkokondylés és végül Kritobulos (MoRAVCSIK 1958: 242-243). Később a név (valószínúleg görög fordításból készült) ószláv forrásokban is felbukkan ugyanebben a jelentésben (THALLóCZY 1896).

A Паíoveৎ népnév magyarokra történő használata tehát „tudós” jellegü, a klasszikus szerzőket még a tulajdonnevek átvételében is követni igyekvő irodalmi körök törekvéseit tükrözi.

GYÓNI MÁTYÁS eredményeinek ismertetése során az idézett Laonikos-szöveghelyre is kitér (GYÓNI 1938: 39). Mint mondja a Пхíoves magyarokkal való azonosítása „,a két nép lakóhelyének közismert azonosságán” nyugszik. Laonikos eljárása ennélfogva GYÓNI szerint jogos, „,mert maguk a magyarok is (bizonyára általa [ti. Laonikos által] ismert latin nyelvü történeti müvekben vagy oklevelekben) s az ola-

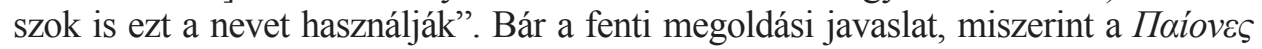
azonosítása a magyarokkal stilisztikai archaizmus, alapvetően helyes, ha összegezzük a paionokra vonatkozó - meglehetősen szerény - ismereteinket (LENK 1942: 24032408), azonnal világossá válik, hogy GYÓNI érvelésében kimaradt egy szem a láncból.

4. Paionok és pannonok. Hérodotos, aki mint tudjuk Laonikos legfőbb mintaképéül szolgált, lényegében mindent elmond, amit a paionokról tudunk (V, 13; MURAKÖZY GYULA fordításában): „Paionia különben a Strymón folyó mellett fekszik, amely nincs messze a Helléspontostól, lakói pedig a trójai eredetủ teukrosok 


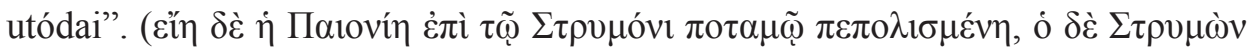

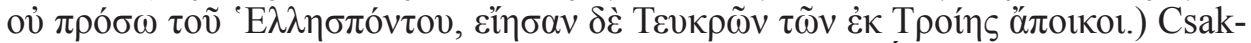
hogy a Strymón folyó a mai Bulgária területén ered és az Égei-tengerbe torkollik, vagyis megállapíthatjuk, hogy a hajdani Paionia lakói, a valószínúleg thrák-illyr eredetü paionok nem Magyarország területén éltek, más szóval a lakóhely földrajzi azonosságán alapuló azonosítás ezúttal nem jöhet szóba. Ráadásul - amennyire tudom - sem a magyarok saját magukra, sem az olaszok a magyarokra nem használták a paion nevet, így Laonikos magyarázatul szánt megjegyzésének értelméhez sem jutottunk közelebb. Mindez természetesen GYÓNI számára is egyértelmű volt, talán túlságosan is egyértelmü, hiszen csakis így for-

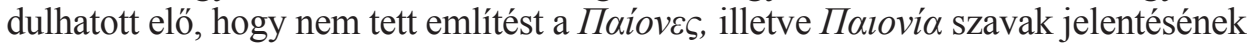
módosulásáról, holott erre korábban már DARKÓ (1910: 53-54) is kitért.

A szempontunkból döntő jelentőségü hibát, a paionok téves azonosítását először minden bizonnyal a Kr. u. 1-2. században müködö történetíró, alexandriai Appianos követte el. Ö ugyanis ös s z e téve s z t e t te, vagy ha úgy tetszik, rosszul azonosította a paionokat a p a n n o n o k k a l, a Pannonia néven provinciává szervezett terület lakóival (MóCSY 1962: 516-776, kül. 708-716). Müvének kilencedik könyvében, az illyriai háborúkat tárgyaló részben Appianos a következőket mondja (Illyr. 40): „A paionok az Istros (= Duna) mentén élő nagy népcsoport [...]A görögök paionnak nevezik öket, a rómaiak pedig

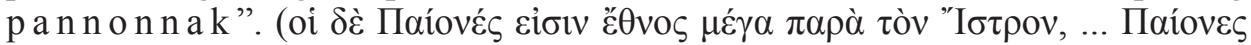

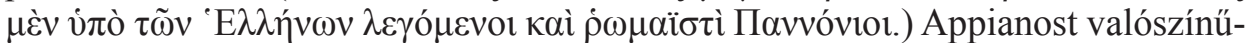

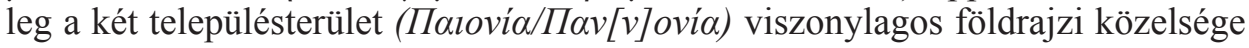

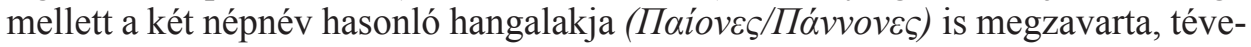
dése pedig a cáfolatok ellenére makacsul tartotta magát.

Appianos fenti állításával leginkább egy másik császárkori szerző, Cassius Dio szállt szembe, márpedig ő valóságos szakértője a pannon-kérdésnek, mert mint magáról elárulja (XLIX, 36, 4): „Kinevezést nyertem a Felső-Pannoniának hívott terület élére, így aztán az összes körülmény pontos ismeretében nyilatko-

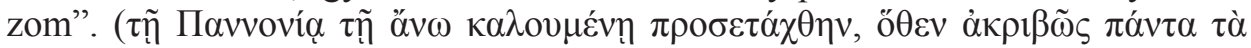

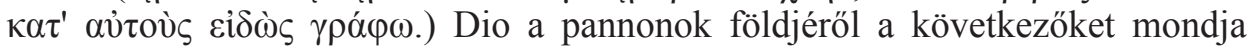
(XLIX, 36, 2): „A pannonok Dalmatia közelében élnek, az Istros folyó partján,

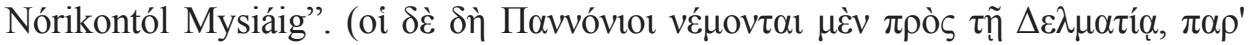

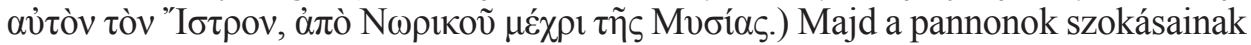
ismertetése után említést tesz a nép nevének eredetéről is (XLIX, 36, 5): „Nevüket onnan kapták, hogy hosszú ujjú chitónjaikat bizonyos sajátos módon foszlányokra vágott és pannosnak (= rongy) nevezett ruhadarabokból varrják. Akár ezért, akár

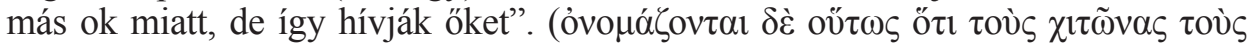

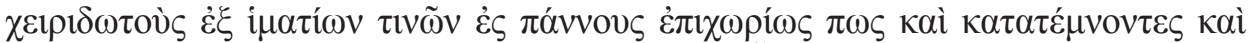

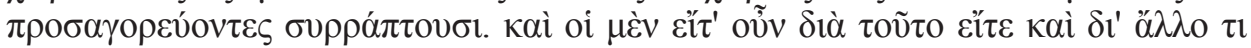

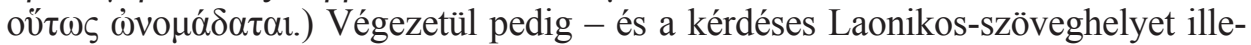
tően ez a legfontosabb mondata - kitér a paion, illetve a pannon népnevek azonosítására is (XLIX, 36, 6): „A görögök közül e g y e s e k t u d a t la n sá g u k b a n pai onnak nevezik őket: ez kétségtelenül egy régi név, csak éppen nem az itt élöké, hanem inkább a Rhodopén és a közelében található, jelenleg egészen a 
tengerig húzódó Makedoniában lakók neve. Emiatt én amazokat paionnak, ezeket pedig pannonnak mondom, ahogyan ők is hívják magukat és a ró-

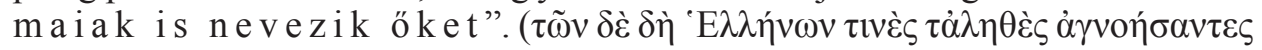

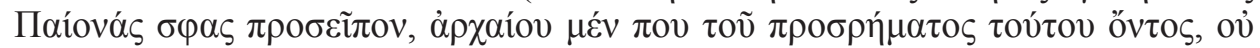

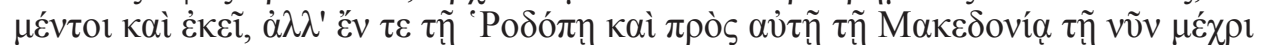

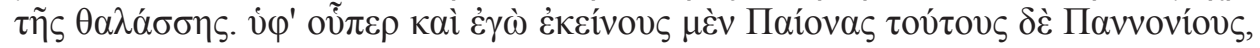

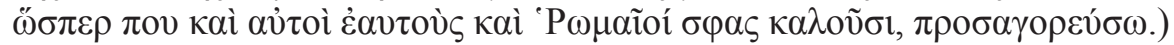

Itt talán érdemes megállnunk egy pillanatra. Cassius Dio történeti múve nagy népszerüségnek örvendett Bizáncban. A hatalmas terjedelmü munkából többen (Zónaras, Xiphilinos) kivonatot készítettek, a fennmaradt kéziratok közül pedig az egyik legfontosabb éppen Laonikos idősebb kortársának, Béssariónnak a közremüködésével került Konstantinápolyból Itáliába. Laonikos így elvileg ismerhette, sőt valószínűleg ismerte is Dio történeti müvét. Ennek ellenére forrásul aligha használta. Bár Cassius Dio fentebb idézett utolsó mondata formai szempontból erősen emlé-

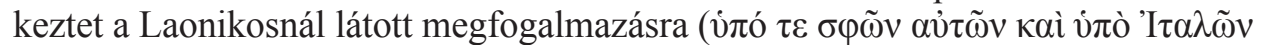

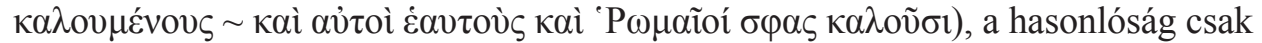
látszólagos, a két mondat tartalma ugyanis homlokegyenest ellentétes. Dio amellett, hogy felismeri a téves névhasználat okát (erőltetett archaizálás), éppenséggel elutasítja azt a paion-pannon azonosítást, ami Laonikos és a többi bizánci szerző számára kiindulópontul szolgált a paion-pannon-magyar népek azonosításához.

Laonikos és Appianos idézett szövege között ugyan némileg halványabban ta-

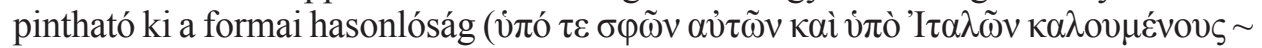

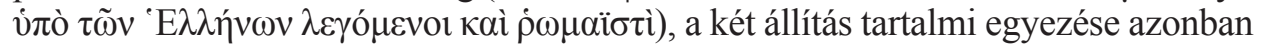
végső soron egyértelmü.

Dio próbálkozása a téves azonosítás hárítására hiábavalónak bizonyult. A bizánciak jóvátehetetlenül összemosták a paionokat és a pannonokat. A helyzetet tökéletesen jellemzi Ióannés Lydos mondata: „Pannoniát a görögök a jóhangzás miatt, és mert kerülni akarták az új szó használatával járó barbarizmust, Paioniának

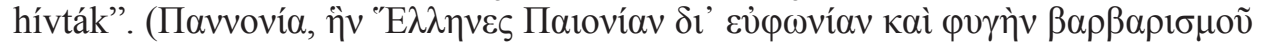

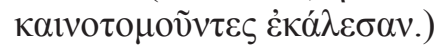

Laonikos számára nagyon fontos volt saját görögsége. Ö már nem a római birodalom képviselöjének vagy örökösének, hanem hangsúlyozottan görögnek tekintette magát. Ezért amikor az archaizálás szándékával mindenképpen valamilyen, a klaszszikus szerzőknél már előforduló népnévvel akarta a magyarokat megnevezni, minden bizonnyal szándékosan döntött úgy, hogy a szinonimának tekintett nevek közül a „latinos” pannon népnév helyett inkább a „görögös” paion alakot választja. Döntését befolyásolhatta, hogy példaképe, Hérodotos is használta a Пaíoveৎ népnevet.

Már csak azt kell megválaszolnunk, hogyan értette Laonikos, hogy mind maguk a magyarok, mind az itáliaiak ezt a nevet használják. Másképpen fogalmazva, azt kell bizonyítanunk, hogy a pannon nevet csakugyan használták mind a magyarok saját magukra, mind az itáliaiak a magyarokra, és erről a névhasználatról Laonikosnak lehetett tudomása. Ehhez azonban a magyarokra vonatkozó latin nyelvü középkori forrásanyagot kell segítségül hívnunk. Szerencsére nem szükséges teljes áttekintésre törekednünk - az átláthatatlanul hatalmas anyag miatt ezzel hiába is próbálkoznánk-, elegendőnek látszik, ha ezúttal néhány, a fenti tételt igazoló adatot említünk. 
5. A magyarok mint pannonok. A középkori latin nyelvü források esetében is igaz mindaz, amit fentebb a bizánci névanyag kutatásáról mondtunk: egy puszta konkordancia, a Pannonia, Pannonius, Pannones szavak előfordulási helyeinek felsorolása és számba vétele nem sokat segít (vö. pl. SRH. 1: 538-539, SRH. 2: 666-667). Ha azonban kizárólag a magyarokra vonatkozó névhasználatot vizsgáljuk (HÓMAN 1917, 1918), megállapíthatjuk, hogy a görög nyelvü forrásokban kitapintott archaizálás a latin szövegek esetében a népnévre egyáltalán $\mathrm{n}$ e m j e 11 e m z ő, szinte kizárólag az országnevet illetően igazolható, mégpedig arra is csak egy rövid időszakra vonatkozóan. A nyugati krónikások a Kárpát-medencében letelepedő magyarokat ugyanis többnyire Ungri (Ungarii), később Hung(a)ri néven emlegetik, csak az országot hívják változatlanul Pannoniá-nak, noha a hajdani provincia az újonnan létrejött magyar királyság (Ungaria/Hungaria) területének csak egy kisebb részét jelenti.

Egészen a 11-12. századi forrásokhoz kell visszanyúlnunk, hogy a magyarpannon azonosítást érdemben igazoló eredményt találjunk. A magyarországi írástudók ekkor még a Pannonia országnév mellett né hán y e s e tb e n használták a Pannonii népnevet a magyarokra, sőt, időnként még a rex Pannoniorum elnevezés is fel-feltünik a magyar király megnevezéseként (a források részletes felsorolását 1. HÓMAN 1917; vö. HÓMAN 1918: 20-24). Nagyjából Szent László király halála után (1095) azonban megváltozik a gyakorlat, a 'magyarok' jelentésben alkalmazott Pannonii népnevet kiszorítja az Ungari (Hungari) alak, s utóbbi(ak) használata Laonikos művének keletkezésekor, a 15. század középső harmadában már általánosnak tekinthetö. Fentiek alapján tehát túlságosan merész felvetésnek tünik, hogy az ifjúkorát a peloponnésosi Mystrasban töltő Laonikos ismert olyan, a müködése előtt több mint 300 évvel korábban Magyarországon keletkezett latin nyelvü szövegeket, melyek a magyarokat Pannonii néven említik. Ha elméletileg lehetett is így, mindez n e m valós zín ü és bizonyíthatatlan.

Laonikos azonban egy másik, sokkal valószínübb módon is értesülhetett Pannonius nevet viselö magyarokról. A Pannonius melléknév 'magyar' jelentésben való használatának hagyományát ugyanis a 15 . század végén és a 16. század elején múködő magyar humanisták és egyházi személyek újjáélesztették. A külföldi, mégpedig elsősorban itáliai tanulmányokat folytató magyarok származásuk megjelölésére - a szintén előforduló Ungarus, de Ungaria jelzők használata mellett - előszeretettel vették fel a Pannonius melléknevet is, és ebben az esetben házigazdáik, a latinul beszélő mủvelt nyugatiak is értelemszerüen így nevezték őket. A Pannonius néven emlegetett magyarok katalógusa még úgy is viszonylag terebélyesnek mondható, ha kizárólag Laonikos kortársait vesszük számba. Adataink alapján ezek közül is az ismertebbek közé tartozott a Hunyadi János környezetében szolgáló A ndre a s P a n n o n i u s karthauzi szerzetes (VERESS 1941: 367-368), a Párizsban doktorátust szerző, majd bő évtizeden át Padovában tanító pálos teológus, Mi cha el Pa n n o ni u s (Veress 1941: 158), a L a d i s l a u s P an n o n i u s néven is emlegetett Vetési László költő (HEGEDÜs 1898: 470-471), vagy a név leghíresebb viselője, a szintén költő J a nu s P a n n o n i us.

Leginkább talán a humanista körökben ünnepelt Janusról feltételezhetjük, hogy nemcsak népszerüségének, hanem felvett melléknevének a híre is eljutott, el- 
juthatott Laonikos fülébe. Talán közvetlenül is - adatok híján ez valószínűleg soha nem fog kiderülni -, de egy másik Chalkokondyléstől, az Itáliában páratlan karriert beteljesítő $\mathrm{D}$ é m é tri o s $\mathrm{Ch}$ a l k o k o n d y lé s tő 1 egészen bizonyosan értesülhetett - akár levélben, akár vélelmezett személyes látogatásai során - Pannonius nevet használó magyarokról. A két Chalkokondylés kapcsolattartása ugyanis meglehetősen biztosnak látszik, mert Laonikos és Démétrios nemcsak név-, hanem (bizonytalan fokon) vérrokonok is voltak.

A Rómában (1449), Perugiában (1450-től), Padovában (1463-tól), Firenzében (1479-től) és Milanóban (1491) is rendkívül eredményesen müködő Démétriosnak lehettek magyar tanítványai, de egyéb ügyekben is könnyen összekerülhetett magyarokkal (követjárás stb.). Ami Janust illeti, ő 1447 és 1458 között tartósan Itáliában (főleg Ferrarában és Padovában) tartózkodott, 1465-ben pedig Hunyadi Mátyás diplomatájaként tett olaszországi körutazást a törökellenes szövetség létrehozása ügyében (ekkor ismerkedett meg egy másik Pannoniusszal, Andreaszszal). Démétrios és Janus kapcsolati hálója és néhány egyéb adat is egyértelműen arról tanúskodik, hogy ismerhették egymást. Az a Marsilio Ficino például, aki 1469. április 5-én Janusnak ajánlotta a platóni Lakomához írt kommentárját (In Convivium Platonis de amore), Démétrios baráti köréhez tartozott (HuSZTI 1925: 28-29). De akad ennél beszédesebb tény is: mikor IV. Sixtus pápa követségének tagjaként Giovanni Lorenzi 1472. április 24-én Bécsújhelyen értesül Janus halálának híréről, első dolga, hogy a fájdalmas újságot levélben jelentse Démétriosnak (a levél szövegét idézi HUSZTI 1931: 285). Summa summarum: Démétrios (s így feltehetően Laonikos is) bizonyosan hallott legalább egy magyarról, akire ,a magyarok is és az itáliaiak is" a Pannonius nevet használták.

Hangsúlyozzuk, hogy Laonikos esetében sem zárhatjuk ki, hogy akár személyesen is ismert Pannonius melléknevet viselő magyarokat, de mivel az ő életét illetően a Konstantinápoly eleste (1453) utáni időszakra nézve semmilyen adatunk nincs, mindez feltételezés marad. Fentiek alapján azonban most már ennek ellenére is érteni véljük Laonikos állítását: „ők maguk is és az itáliaiak is ezt a nevet (tudniillik a pannon nevet, ami Laonikos számára azonos a paion névvel) használják".

6. Összegzés. Végső soron tehát a következőket mondhatjuk a névhasználat magyarázatául. Lakhelyük viszonylagos közelsége és a névalakok hasonlósága miatt már ókori szerzők (Appianos) összekeverték és egymással tévesen azonosították a paion és pannon etnikumot. A téves azonosítást a cáfolat ellenére (Cassius Dio) a bizánci szerzők átvették, a két népnevet pedig idővel szinonimaként hasz-

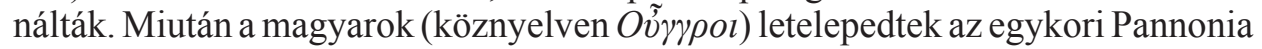
provincia területén, az archaizáló irodalmi ízlés szabályainak megfelelően rájuk is

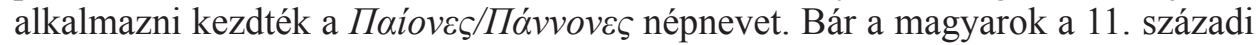
latin nyelvü írásos forrásaikban még előszeretettel használták magukra ugyanezt az archaizáló terminológiát (Pannonia, Pannonii, Pannonius, rex Pannoniorum), ezt később kiszorították a köznyelvi (H)ung(a)ri, (H)ung(a)ria stb. formák. Az archaizáló elnevezéseket a 15. században a tanulmányaikat külhonban, elsősorban Itáliában folytató magyar diákok saját magukra alkalmazott névhasználati gyakorlata élesztette fel. Ennek nyomán a külföldi (itáliai) humanisták is átvették 
és alkalmazni kezdtek a Pannonius melléknevet magyarok megnevezésére. Közöttük is kiemelkedő ismertséggel rendelkezett Janus Pannonius, aki személyes kapcsolatban állt Laonikos Itáliában müködő rokona, Démétrios Chalkokondylés baráti és tanítványi körével. Laonikos tehát a magyarok Pannonii nevéről elvben tudomást szerezhetett mind írásos, mind szóbeli forrásból (Démétrios révén), de Pannonius nevet viselő személlyel való esetleges személyes kapcsolatát sem zárhatjuk ki. Így aztán indokoltnak tekinthette és minden további nélkül használhatta a pannonokkal azonosított magyarok népneveként a szinonimának tekintett

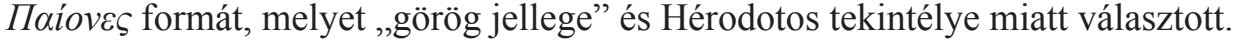

Kulcsszók: Laonikos Chalkokondylés, a magyar népnév Bizáncban, paion, pannon, archaizálás, Démétrios Chalkokondylés, Janus Pannonius.

\section{Hivatkozott irodalom}

BENKÖ LORÁND 2009. A Szovárd-kérdés. Akadémiai Kiadó, Budapest.

CzeBE, Julius 1925. Ephraim, Missionär von Tovpкía. Ein Beispiel für den Bedeutungswandel eines byzantinischen Landnamens. Byzantinische Zeitschrift 25: 106-113. http://dx.doi.org/10.1515/byzs.1925.25.1.106

DARKÓ JENÖ 1910. A magyarokra vonatkozó népnevek a bizánczi iróknál. Magyar Tudományos Akadémia, Budapest.

DARKÓ, EUGEN 1912. Die auf die Ungarn bezüglichen Volksnamen bei den Byzantiner. Byzantinische Zeitschrift 21:472-487. http://dx.doi.org/10.1515/byzs.1912.21.2.472

GYÓNI MÁTYÁs 1938. Magyarország és a magyarság a bizánci források tükrében. Pázmány Péter Tudományegyetem Görög Filológiai Intézet, Budapest.

HEGEDÜS ISTVÁN 1898. Irodalomtörténeti tarlózások az olasz könyvtárakban III. Irodalomtörténeti Közlemények 8: 465-480.

HóMAN BÁLINT 1917. A magyar nép neve a középkori latinságban I-II. Történelmi Szemle 6: 129-158, 240-258.

HóMAN BÁLINT 1918. A magyar nép neve a középkori latinságban III. Történelmi Szemle 7: $1-22$.

HusZTI JózSEF 1925. Platonista törekvések Mátyás király udvarában. Minerva, Pécs.

HuszTI JózSEF 1931. Janus Pannonius. Janus Pannonius-Társaság, Pécs.

Kaldellis, Anthony 2012. The Date of Laonikos' Histories. Greek, Roman, and Byzantine Studies 52: 111-136.

KALDELlis, Anthony 2014a.: Laonikos Chalkokondyles. The Histories I-II. Harvard University Press, Cambridge MA - London.

Kaldellis, ANTHONY 2014b. A New Herodotos. Laonikos Chalkokondyles on the Ottoman Empire, the Fall of Byzantium, and the Emergence of the West. Dumbarton Oaks Research Library and Collection, Washington.

Lenk, Brunhilde 1942. Paiones. In: Kroll, Wilhelm - MitTelhaus, Karl Hrsg., Pauly-Wissowa Realencyclopädie XVIII/2. Alfred Druckenmüller Verlag, Stuttgart. 2403-2408.

MisKOLCZI GyUla 1913. Adatok Laonikos Chalkondyles életrajzához. Történeti Szemle 2: $198-214$.

MóCsY, ANDRÁs 1962. Pannonia. In: ZIEGLER, KONRAT Hrsg., Pauly-Wissowa Realencyclopädie Suppl. IX. Alfred Druckenmüller Verlag, Stuttgart. 516-776. 
MoRAVCSIK, GYUlA 1929-1930. Die archaisierenden Namen der Ungarn in Byzanz. Byzantinische Zeitschrift 30: 247-253. http://dx.doi.org/10.1515/bz-1929-0145

MORAVCSIK GYULA 1934. A magyar történet bizánci forrásai. Magyar Történelmi Társulat, Budapest.

MORAVCSIK, GYUla 1958. Byzantinoturcica I-II. Akademie-Verlag, Berlin.

MORAVCSIK, GYULA 1966. Klassizismus in der byzantinischen Geschichtsschreibung. In: Wirth, Peter Hrsg., Polychronion. Festschrift Franz Dölger zum 75. Geburtstag. C. Winter, Heidelberg. 366-377.

NiCOLOUdis, NiCOlaOs 1996. Laonikos Chalkokondyles. A Translation and Commentary of the Demonstrations of Histories. Book I-III. Historical Publications St. D. Basilopoulos, Athens.

SRH. = Scriptores rerum Hungaricarum tempore ducum regumque stirpis Arpadianae gestarum 1-2. Szerk. SzENTPÉTERY IMRE. Második, bővített kiadás. Gondozta SzOVÁK KorNÉL - VESZPRÉMY LÁSZLÓ. Nap Kiadó, Budapest, 1999.

Talbot, Alice-Mary 1991. Laonikos Chalkokondyles. In: KaZHDAn, AleXander P. ed., The Oxford Dictionary of Byzantium I. Oxford University Press, New York Oxford. 407.

THALlÓCZY LAJOS 1896. Adalék az ó-hit történetéhez Magyarországon. Századok 30: 199-206.

VERESS ENDRE 1941. Olasz egyetemeken járt magyarországi tanulók anyakönyve és iratai 1221-1864. Olaszországi magyar emlékek III. Magyar Tudományos Akadémia, Budapest.

WURM, HERBERT - GAMILlSCHEG, ERNST 1992. Bemerkungen zu Laonikos Chalkokondyles. Jahrbuch der Österreichischen Byzantinistik 42: 213-219.

\section{Laonikos on the ethnonyms of the Hungarians}

Laonikos Chalkokondyles mentions several data related to the history of the Hungarians. Here, I discuss the problematic use of the ethnonym Пaioves used in reference to the Hungarians. This form occurs from the end of the 12th century, and becomes widespread in the 14th-15th centuries. Its use is scholarly, and is preferred by a trend which aims to imitate the antique authors even by borrowing proper names from them. Due to the relative proximity of their homelands and the similarity of the names, the antique authors had confused the ethnic groups of the Paeoneans and the Pannonians. The incorrect identification was borrowed by the Byzantine authors, and the two ethnonyms started to be used as synonyms. After the Hungarians had settled down in the territory of

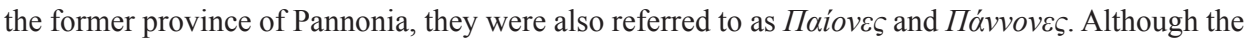
Hungarians used the same Latin terminology to refer to themselves in their written sources until the 12th century, it was probably unknown to Laonikos. However, he could have heard of Hungarian humanists learning in Italy and using the name Pannonius from his relative Demetrios, who might even have known some of them personally.

Keywords: Laonikos Chalkokondyles, the ethnonym of the Hungarians in Byzantine sources, Paeonean, Pannonian, archaism, Demetrios Chalkokondyles, Janus Pannonius.

MÉSZÁROS TAMÁS

Eötvös Collegium

Byzantium Központ 